Saudi Journal of Business and Management Studies Abbreviated Key Title: Saudi J Bus Manag Stud ISSN 2415-6663 (Print) |ISSN 2415-6671 (Online) Scholars Middle East Publishers, Dubai, United Arab Emirates Journal homepage: https://saudijournals.com/sjbms

Original Research Article

\title{
Overall Equipment Effectiveness Improvement on Cutting Machine by Minimizing Six Big Losses
}

\author{
Rosalendro Eddy Nugroho ${ }^{1 *}$, Syifa Khoirudin ${ }^{2}$ \\ ${ }^{1}$ Lecturer of Master Manajemen, Mercu Buana University, Jakarta, Indonesia \\ ${ }^{2}$ Student of Master Manajemen, Mercu Buana University, Jakarta, Indonesia
}

DOI: $10.36348 /$ sjbms.2020.v05i01.011 | Received: 20.01.2020 | Accepted: 27.01.2020 | Published: 29.01.2020

*Corresponding author: Rosalendro Eddy Nugroho

\section{Abstract}

This study aims to analyze the achievement of Overall Equipment Effectiveness on the cutting machine by minimizing the Six Big Losses that occur on the cutting machine. The research data are monthly data for the period January 2017 to June 2018. The sampling method used was purposive sampling. From a population of 18 carline areas with a total of 148 cutting machine units, 3 carline areas with the lowest OEE achievement as a sample. The analytical method used in the study is the analysis of OEE calculations and six big losses with a fishbone diagram analysis. The results showed the cause of the OEE value not yet achieved in the Toyota Bfree carline was the low Performance Efficiency results of $72.56 \%$ and the high Equipment Failure losses of $94.57 \%$. In the Toyota Hiace carline is the low Performance Efficiency results of $69.25 \%$ and the high Equipment Failure losses of $88.70 \%$. On the Toyota Vitz carline is the low availability of $76.81 \%$ and the high Equipment Failure losses of $87.01 \%$. With suggestions for improvements given to increase the value of OEE companies based on factors Man, Machine, Method, Material, and Environment.

Keywords: Cutting Machines, Fishbone Diagrams, Overall Equipment Effectiveness, Six Big Losses.

Copyright @ 2020: This is an open-access article distributed under the terms of the Creative Commons Attribution license which permits unrestricted use, distribution, and reproduction in any medium for non-commercial use (NonCommercial, or CC-BY-NC) provided the original author and source are credited.

\section{INTRODUCTION}

The industrial sector has always tried to minimize their operational cost and maximize their asset usage. The efficiency of production and industrial effectivity depends on the effectivity of tools that are being used. In short, Overall Equipment Effectiveness (OEE) is basically seen to calculate performance efficiency [1].

In order to determine what causes the result of the below standard OEE score, we will use the Six Big Losses calculation. Six Big Losses are six points that decrease the effectivity of a standard machine that must be avoided by a company [2].
$\mathrm{XYZ}$ manufacture company was established in 1989 at Indonesia. XYZ Manufacture Company occupied the automotive manufacture sector that produced vehicle components, especially wiring harness for cars. There are a few steps in every production, such as pre assy, final assy, inspection, and finish goods. Cutting machines holds an important part in the production process. Cutting machines must produce wire with cutting length and quality which suited the standard quality that the company prescribed. Below is the OEE data of cutting machines between the period of 2017 and January - June 2018: 


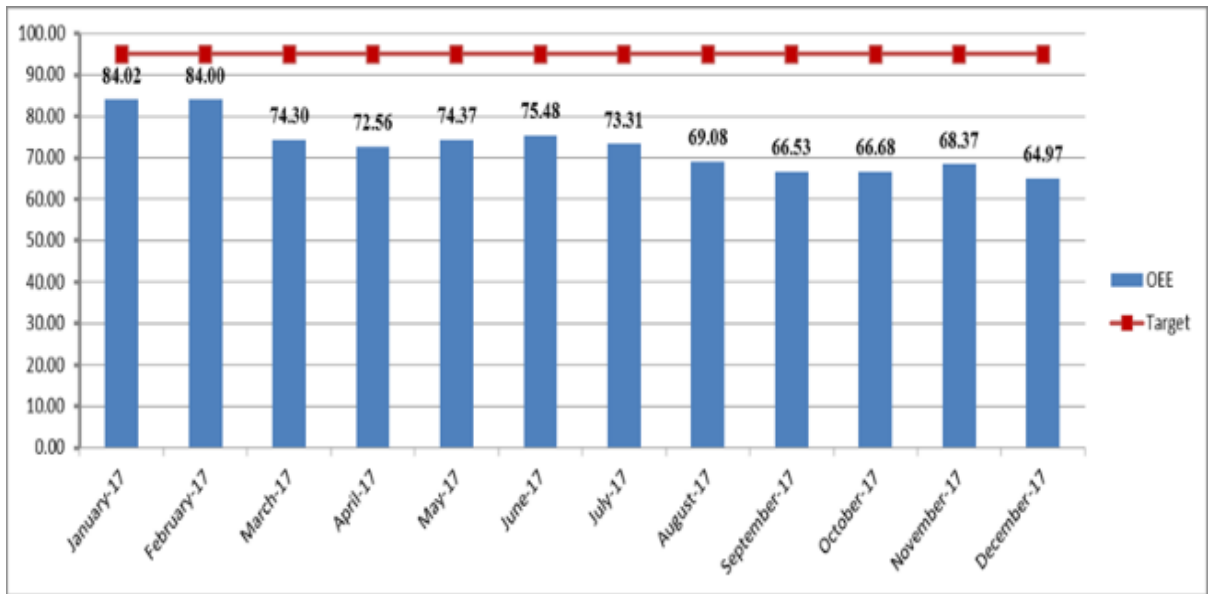

Fig-1: XYZ Manufacture Company's cutting machine OEE scores in 2017 Source: Maintenance Department (2017)

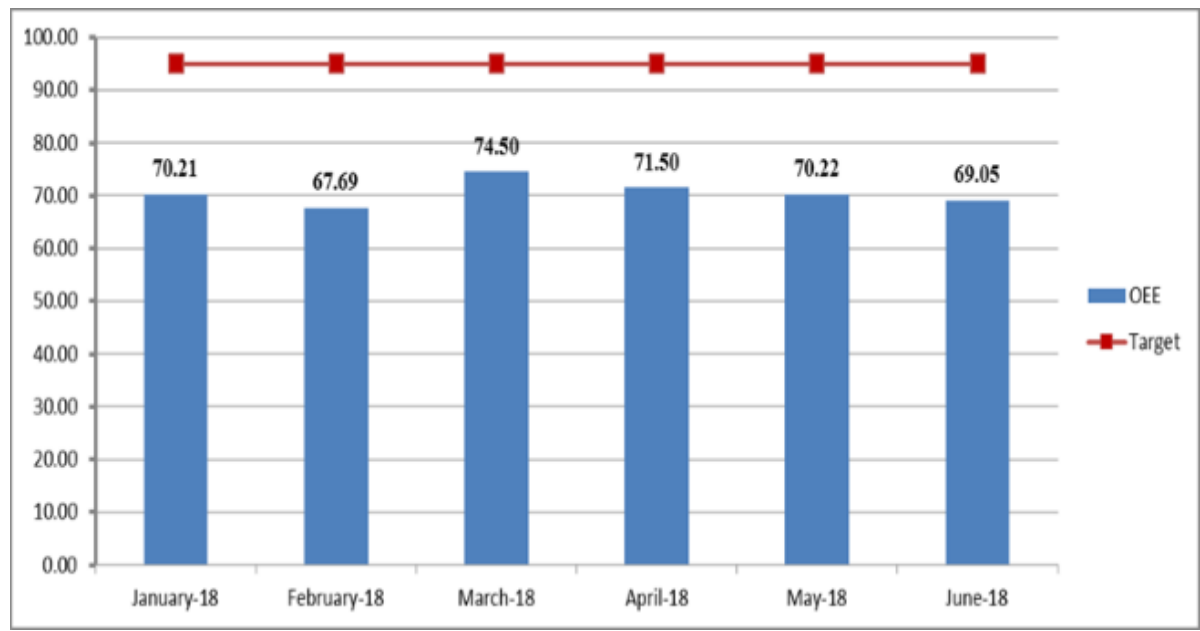

Fig-2: XYZ Manufacture Company's cutting machine OEE scores in January-June 2018 Source: Maintenance Department (2018)

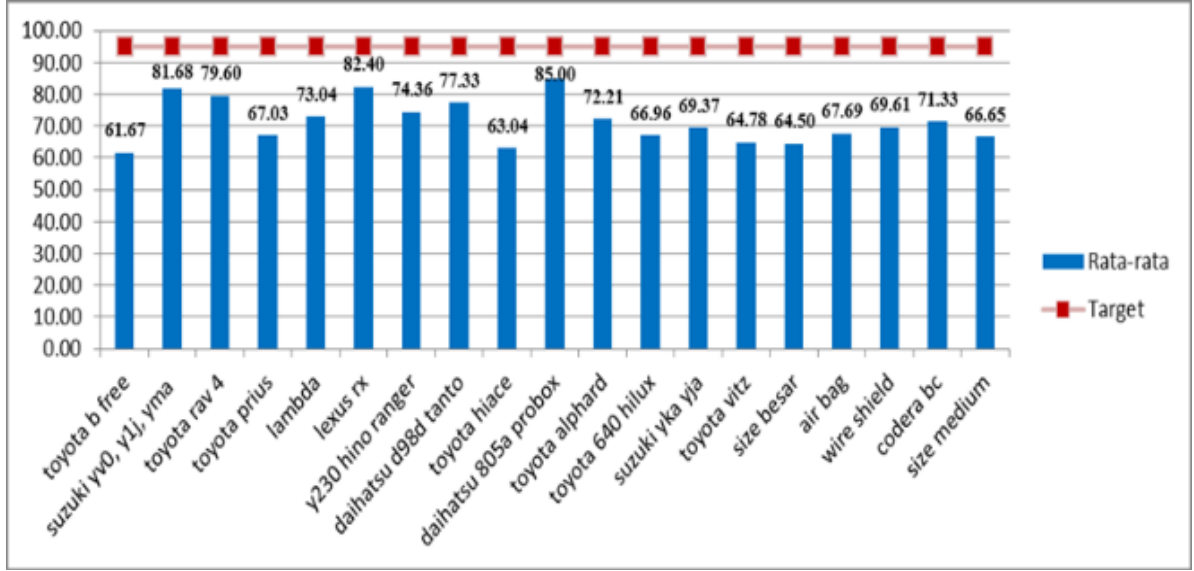

Fig-3: OEE score of each carline production in January 2017 - June 2018

OEE score achievement per carline in January 2017 - June 2018 shows the lowest 3 OEE score achievement on cutting machine are carline Toyota B Free with $61,67 \%$, carline Toyota Hiace with $63,04 \%$, and carline Toyota Vitz with $64,78 \%$.

\section{REVIEW OF LITERATURE}

Total Productive Maintenance (TPM) is a management principle to increase the productivity and production efficiency of a company by effectively using machines [3]. The concept of Total Productive Maintenance is used to maintain the best equipment to avoid unexpected damage, speed loss, and quality defects [4]. 
Overall Equipment Effectiveness (OEE) is really valuable for accounting and identifying the sources of deficiency in a production. OEE is also very crucial for performance optimization of the current capacity, halt a big investment, decrease overtime expenses, variability reduction process, operator performance improvement, and reduce changeover time [5]. In Eng and Choi's research, [6] concluded that OEE is an important metric that provides information about the root causes of lost time and production. OEE is also a tool that can help a company to optimize performance without large investments.

According to Nakajima Vice Chairman of the Japan Institute of Plant Mintenance in the research Nurfaizah, et al. [7] The Six Big Losses are six major losses incurred, which are part of TPM's actions to eliminate these six losses. The six major losses can be calculated in OEE calculations. According to Nakajima in the study of Alvira et al. [2] activities and actions undertaken not only focus on preventing damage to the machine / equipment and minimizing machine / equipment downtime.

Fishbone Diagram (also known as Ishikawa Diagram or Cause-and-Effect Diagram) is a graphic technique to show the causes of some events or phenomena. Specifically, fish bone diagrams (shaped similar to fish skeletons) are a tool commonly used for cause and effect analysis to identify complex interactions from the cause of a particular problem or event [8].

\section{RESEARCH METHODOLOGY}

In this research, the writer uses a quantitative research method in a form of a case study where the research was done by using data and information from a problem to come up with thorough comprehension that will be used to solve the current problem. On the other hand, the descriptive model will be used as the research design. Descriptive design is used to describe the result of processing and analyzing each of the variables in the research.

\section{Population and Sample}

The population in this research is the whole cutting machine on every carline of PT. EDS Manufacturing Indonesia in a total of 18 carline areas which consist of 148 units of cutting machines. Samples in this research are the three lowest carlines area in the OEE score, which are: carline Toyota B Free, carline Toyota Hiace, and carline Toyota Vitz.

\section{Collecting Data Method}

Data collection methods used in this study are combining two methods, there are primary data collection methods and secondary data.

Primary data is data obtained from its main source by conducting field studies directly to companies or observatives. Data needed to help the analysis process using fishbone diagrams, interviewing operators who operate machines related to man factors and methods, as well as making observations to companies related to machine, materials, and environment factors.

Secondary data is data in the form of company documentation, which is related to maintenance report data, engineering reports related to cutting machines, as well as relevant studies in writing this thesis, as for the study sources such as journals, books, and others.

\section{Data Analysis Method}

OEE Score Achievement Analysis:

Calculation of the OEE score comes from 3 calculation indicators as shown below [9]

Availability $=\frac{\text { Loading time-Downtime }}{\text { Loading time }} \times 100 \%$ (1)

Performance Efficiency $=\frac{\text { Actual Production } \times \text { Ideal Cycle Time }}{\text { Operation Time }} \times 100 \%$ (2)

Quality rate $=\frac{\text { Actual Production-Total Defect }}{\text { Actual Production }} \times 100 \%$ (3)

To acquire the OEE score we must apply the calculation below:

OEE $=$ Availability $\times$ Performance $\times$ Quality (4)

Six Big Losses Score Achievement Analysis

The loss that can cause a decrease in the effectiveness value is known as the six big losses. The six big losses are as follows: [10]

Equipment failure (Losses because of inoperable tools)

$=\frac{\text { Total Breakdown Time }}{\text { Loading } \text { Time }} \times 100 \%$ (5)

Set-up and adjustment (Losses because of installation and adjustment)

$=\frac{\text { Total Set Up and Adjustment Time }}{\text { Loading Time }} \times 100 \%$ (6) 
Idling and minor stoppages (Losses because of idling on production or minor stoppage)

$=\frac{\text { Non Productive Time at Set Up and Adjustment Time }}{\text { Loading Time }} \times 100 \%(7)$

Reduced speed (Losses because of the decreasing of speed)

$=\frac{\text { Operating Time }-(\text { Theoritical Cycle Time } \times \text { Processed Amount })}{\text { Loading Time }} \times 100 \%$

Process defect (Losses because of defect product and/or because reprocess work of the product) $=\frac{\text { Theoritical Cycle Time } \times \text { Rework }}{\text { Loading Time }} \times 100 \%(9)$

Reduced yield losses (Losses because of early production process until achieving stable product) $=\frac{\text { Theoritical Cycle Time } \times \text { Scrap }}{\text { Loading Time }} \times 100 \%$ (10)

\section{RESULTS AND DISCUSSION}

To get the result from the research, calculation on the 3 carlines with the lowest OEE score, which are carline Toyota B Free, carline Toyota Hiace, and carline Toyota Vitz, must be done. Each of the carlines was calculated by looking at the OEE variables. Then, the factor with the lowest percentage is held as a focus to analyze the cause of the low score achievement of OEE on the cutting machine. Next, calculate the variables of the Six Big Losses. After that, the factor with the highest percentage becomes the focus to analyze the cause of the low score achievement of OEE on the cutting machine. Lastly, the result of the analysis of the
OEE and Six Big Losses are calculated with the Fishbone diagram.

\section{OEE Calculation Results}

OEE calculation of the cutting machine was done on the period of January 2017 - June 2017. The calculation based on 3 OEE variables, which are Availability, Performance Efficiency, and Quality Rate, was dealt with the formula that has been mentioned in the data analysis method. Here are the calculation results of the OEE variable for carline Toyota B Free, Toyota Hiace, and Toyota Vitz on the period of January 2017 - June 2018:

Table-1: OEE Result Carline Toyota BFree

\begin{tabular}{|l|l|l|l|l|l|}
\hline No & Month & Availability & Performance Efficiency & Quality Rate & OEE \\
\hline 1 & Jan 17 & $91.20 \%$ & $83.91 \%$ & $100 \%$ & $76.52 \%$ \\
\hline 2 & Feb 17 & $88.48 \%$ & $85.94 \%$ & $100 \%$ & $76.05 \%$ \\
\hline 3 & Mar 17 & $94.68 \%$ & $84.57 \%$ & $100 \%$ & $80.07 \%$ \\
\hline 4 & Apr 17 & $92.73 \%$ & $91.39 \%$ & $100 \%$ & $84.75 \%$ \\
\hline 5 & May 17 & $87.18 \%$ & $88.12 \%$ & $100 \%$ & $76.82 \%$ \\
\hline 6 & Jun 17 & $90.14 \%$ & $76.80 \%$ & $100 \%$ & $69.23 \%$ \\
\hline 7 & Jul 17 & $83.87 \%$ & $65.81 \%$ & $100 \%$ & $55.20 \%$ \\
\hline 8 & Aug 17 & $86.20 \%$ & $72.62 \%$ & $100 \%$ & $62.59 \%$ \\
\hline 9 & Sep 17 & $78.45 \%$ & $74.31 \%$ & $100 \%$ & $58.29 \%$ \\
\hline 10 & Okt 17 & $76.69 \%$ & $67.96 \%$ & $100 \%$ & $52.12 \%$ \\
\hline 11 & Nov 17 & $74.31 \%$ & $69.24 \%$ & $100 \%$ & $51.45 \%$ \\
\hline 12 & Dec 17 & $81.21 \%$ & $61.12 \%$ & $100 \%$ & $49.64 \%$ \\
\hline 13 & Jan 18 & $76.64 \%$ & $64.98 \%$ & $100 \%$ & $49.80 \%$ \\
\hline 14 & Feb 18 & $81.11 \%$ & $70.70 \%$ & $100 \%$ & $57.34 \%$ \\
\hline 15 & Mar 18 & $88.46 \%$ & $70.39 \%$ & $100 \%$ & $62.27 \%$ \\
\hline 16 & Apr 18 & $86.36 \%$ & $65.19 \%$ & $100 \%$ & $56.30 \%$ \\
\hline 17 & May 18 & $81.04 \%$ & $59.71 \%$ & $100 \%$ & $48.39 \%$ \\
\hline 18 & Jun 18 & $81.01 \%$ & $53.39 \%$ & $100 \%$ & $43.25 \%$ \\
\hline Average & $84.43 \%$ & $72.56 \%$ & $100 \%$ & $61.67 \%$ \\
\hline
\end{tabular}

Source: Self elaborated


Table-2: OEE Result Carline Toyota Hiace

\begin{tabular}{|l|l|l|l|l|l|}
\hline No & Month & Availability & $\begin{array}{l}\text { Performance } \\
\text { Efficiency }\end{array}$ & $\begin{array}{l}\text { Quality } \\
\text { Rate }\end{array}$ & OEE \\
\hline 1 & Jan 17 & $89 \%$ & $69.88 \%$ & $100 \%$ & $62.52 \%$ \\
\hline 2 & Feb 17 & $92 \%$ & $73.04 \%$ & $100 \%$ & $67.30 \%$ \\
\hline 3 & Mar 17 & $92 \%$ & $72.12 \%$ & $100 \%$ & $66.41 \%$ \\
\hline 4 & Apr 17 & $94 \%$ & $69.92 \%$ & $100 \%$ & $65.40 \%$ \\
\hline 5 & May 17 & $92 \%$ & $73.71 \%$ & $100 \%$ & $67.47 \%$ \\
\hline 6 & Jun 17 & $92 \%$ & $74.56 \%$ & $100 \%$ & $68.74 \%$ \\
\hline 7 & Jul 17 & $89 \%$ & $66.53 \%$ & $100 \%$ & $59.47 \%$ \\
\hline 8 & Aug 17 & $75 \%$ & $58.97 \%$ & $100 \%$ & $44.31 \%$ \\
\hline 9 & Sep 17 & $87 \%$ & $63.87 \%$ & $100 \%$ & $55.48 \%$ \\
\hline 10 & Okt 17 & $87 \%$ & $62.40 \%$ & $100 \%$ & $54.36 \%$ \\
\hline 11 & Nov 17 & $88 \%$ & $57.52 \%$ & $100 \%$ & $50.62 \%$ \\
\hline 12 & Dec 17 & $89 \%$ & $62.99 \%$ & $100 \%$ & $55.87 \%$ \\
\hline 13 & Jan 18 & $87 \%$ & $68.47 \%$ & $100 \%$ & $59.68 \%$ \\
\hline 14 & Feb 18 & $83 \%$ & $69.77 \%$ & $100 \%$ & $58.05 \%$ \\
\hline 15 & Mar 18 & $93 \%$ & $77.22 \%$ & $100 \%$ & $71.83 \%$ \\
\hline 16 & Apr 18 & $92 \%$ & $79.39 \%$ & $100 \%$ & $73.06 \%$ \\
\hline 17 & May 18 & $86 \%$ & $72.80 \%$ & $100 \%$ & $62.52 \%$ \\
\hline 18 & Jun 18 & $89 \%$ & $73.33 \%$ & $100 \%$ & $65.21 \%$ \\
\hline Average & $89 \%$ & $69.25 \%$ & $100 \%$ & $61.57 \%$ \\
\hline
\end{tabular}

Source: Self elaborated

Table-3: OEE Result Carline Toyota Vitz

\begin{tabular}{|l|l|l|l|l|l|}
\hline No & Month & Availability & $\begin{array}{l}\text { Performance } \\
\text { Efficiency }\end{array}$ & $\begin{array}{l}\text { Quality } \\
\text { Rate }\end{array}$ & OEE \\
\hline 1 & Jan 17 & $82.72 \%$ & $96.49 \%$ & $100 \%$ & $79.82 \%$ \\
\hline 2 & Feb 17 & $78.81 \%$ & $96.39 \%$ & $100 \%$ & $75.97 \%$ \\
\hline 3 & Mar 17 & $78.72 \%$ & $90.86 \%$ & $100 \%$ & $71.53 \%$ \\
\hline 4 & Apr 17 & $92.29 \%$ & $83.56 \%$ & $100 \%$ & $77.12 \%$ \\
\hline 5 & May 17 & $71.04 \%$ & $88.31 \%$ & $100 \%$ & $62.73 \%$ \\
\hline 6 & Jun 17 & $70.03 \%$ & $93.44 \%$ & $100 \%$ & $65.44 \%$ \\
\hline 7 & Jul 17 & $81.00 \%$ & $90.62 \%$ & $100 \%$ & $73.40 \%$ \\
\hline 8 & Aug 17 & $87.83 \%$ & $88.14 \%$ & $100 \%$ & $77.41 \%$ \\
\hline 9 & Sep 17 & $68.59 \%$ & $76.79 \%$ & $100 \%$ & $52.67 \%$ \\
\hline 10 & Okt 17 & $76.47 \%$ & $80.15 \%$ & $100 \%$ & $61.29 \%$ \\
\hline 11 & Nov 17 & $75.44 \%$ & $77.11 \%$ & $100 \%$ & $58.18 \%$ \\
\hline 12 & Dec 17 & $78.75 \%$ & $73.60 \%$ & $100 \%$ & $57.96 \%$ \\
\hline 13 & Jan 18 & $75.46 \%$ & $84.27 \%$ & $100 \%$ & $63.60 \%$ \\
\hline 14 & Feb 18 & $71.09 \%$ & $98.58 \%$ & $100 \%$ & $70.08 \%$ \\
\hline 15 & Mar 18 & $76.85 \%$ & $80.20 \%$ & $100 \%$ & $61.64 \%$ \\
\hline 16 & Apr 18 & $66.71 \%$ & $76.60 \%$ & $100 \%$ & $51.10 \%$ \\
\hline 17 & May 18 & $80.29 \%$ & $73.58 \%$ & $100 \%$ & $59.08 \%$ \\
\hline 18 & Jun 18 & $70.48 \%$ & $71.34 \%$ & $100 \%$ & $50.28 \%$ \\
\hline Average & $76.81 \%$ & $84.45 \%$ & $100 \%$ & $64.96 \%$ \\
\hline
\end{tabular}

Source: Self elaborated

According to the results, the OEE score on the cutting machine of the three carlines has not met the standard of those that the company had set up, which is $95 \%$. By looking at the result, a more thorough analysis should be done to find a solution to fix the OEE score achievement of the company. Based on the result of the OEE calculations above, in order to find the source of the problem for the low achievement on the OEE score on the three carlines, Pareto diagram was used such as below: 


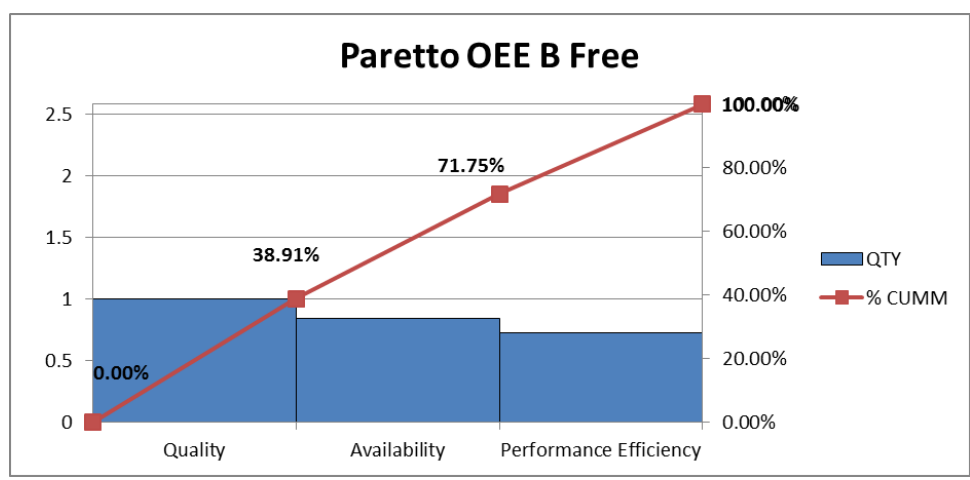

Fig-4: Diagram of OEE Toyota Bfree's Paretto Calculation

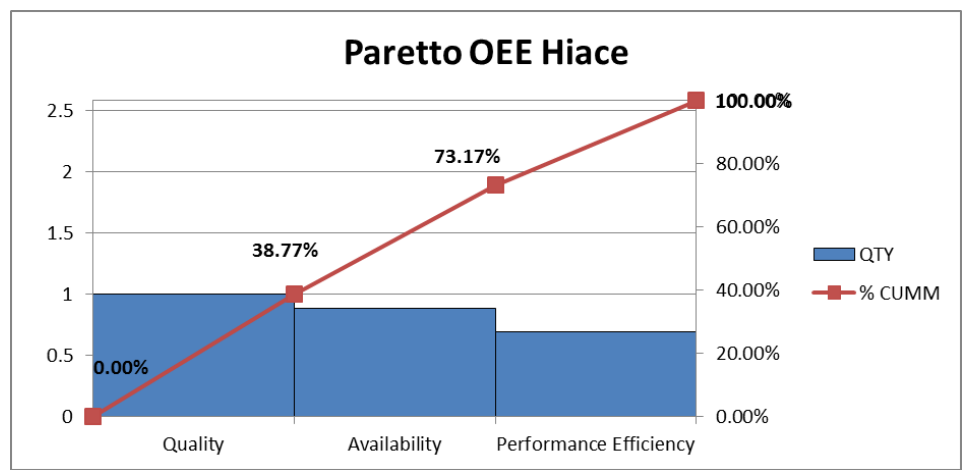

Fig-5: Diagram of OEE Toyota Hiace's Paretto Calculation

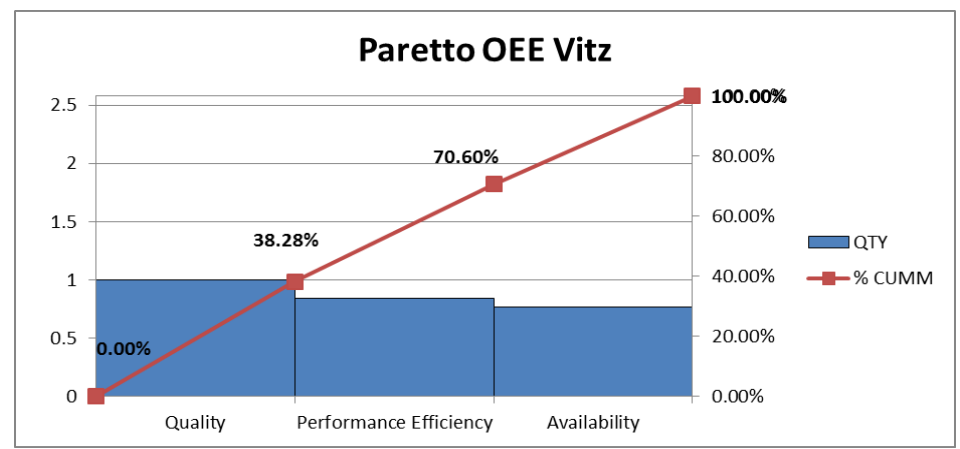

Fig-6: Diagram of OEE Toyota Vitz's Paretto Calculation

Through the Paretto diagram, we found that the lowest score from the OEE calculation on carline Toyota B Free and Toyota Hiace are the scores from Performance Efficiency. On the other hand, the carline Toyota Vitz score is from the Availability. Next, the lowest achievement is set as a focus to fix the OEE score achievement on the three carlines through analyzing the scores with the Fishbone diagram and give the solution to fix the OEE score achievement on carline B Free that is applicable for the company.

\section{Six Big Losses Calculation Results}

The Six Big Losses calculation on the cutting machine was done on the period of January 2017 - June 2017. The calculation was based on six variables of Six Big Losses, which are Equipment Failure, Reduced Speed, Set Up \& Adjustment, Idling Minor \& Stoppage, Process Defect, Reduced Yield Losses, by using the formula mentioned on analysis data method. Below are the calculation results on Six Big Losses variables on carline Toyota B Free, Toyota Hiace, and Toyota Vitz on the period of January 2017 - June 2018:

Table-4: Six Big Losses Result Carline Toyota Bfree

\begin{tabular}{|r|l|r|r|}
\hline No & \multicolumn{1}{|c|}{ Six Big Losess } & Percentage (\%) & Cummulative Percentage (\%) \\
\hline 1 & Equipment Failure & $70.70 \%$ & $70.70 \%$ \\
\hline 2 & Set Up \& Adjustment & $17.04 \%$ & $87.74 \%$ \\
\hline 3 & Idling Minor \& Stoppages & $10.39 \%$ & $98.13 \%$ \\
\hline 4 & Reduced Speed & $1.87 \%$ & $100.00 \%$ \\
\hline 5 & Process Defect & $0.00 \%$ & $100.00 \%$ \\
\hline 6 & Reduced Yield Losess & $0.00 \%$ & $100.00 \%$ \\
\hline \multicolumn{3}{|c}{ Source: Self elaborated }
\end{tabular}


Table-5: Six Big Losses Result Carline Toyota Hiace

\begin{tabular}{|r|l|r|r|}
\hline No & Six Big Losess & Percentage (\%) & Cummulative Percentage (\%) \\
\hline 1 & Equipment Failure & $63.18 \%$ & $63.18 \%$ \\
\hline 2 & Set Up \& Adjustment & $19.30 \%$ & $82.48 \%$ \\
\hline 3 & Idling Minor \& Stoppages & $13.60 \%$ & $96.08 \%$ \\
\hline 4 & Reduced Speed & $3.92 \%$ & $100.00 \%$ \\
\hline 5 & Process Defect & $0.00 \%$ & $100.00 \%$ \\
\hline 6 & Reduced Yield Losess & $0.00 \%$ & $100.00 \%$ \\
\hline
\end{tabular}

Table-6: Six Big Losses Result Carline Toyota Vitz

\begin{tabular}{|r|l|r|r|}
\hline No & Six Big Losess & Percentage (\%) & Cummulative Percentage (\%) \\
\hline 1 & Equipment Failure & $80.86 \%$ & $80.86 \%$ \\
\hline 2 & Set Up \& Adjustment & $10.97 \%$ & $91.82 \%$ \\
\hline 3 & Idling Minor \& Stoppages & $7.53 \%$ & $99.35 \%$ \\
\hline 4 & Reduced Speed & $0.65 \%$ & $100.00 \%$ \\
\hline 5 & Process Defect & $0.00 \%$ & $100.00 \%$ \\
\hline 6 & Reduced Yield Losess & $0.00 \%$ & $100.00 \%$ \\
\hline
\end{tabular}

Source: Self elaborated

From the Six Big Losses calculation above, the losses that were found on the three carlines can be analyzed to fix the main problem to minimize the losses that happened. As to how to find the main problem on the low achievement on the OEE score on the three carlines, Paretto Diagram was used such as below:

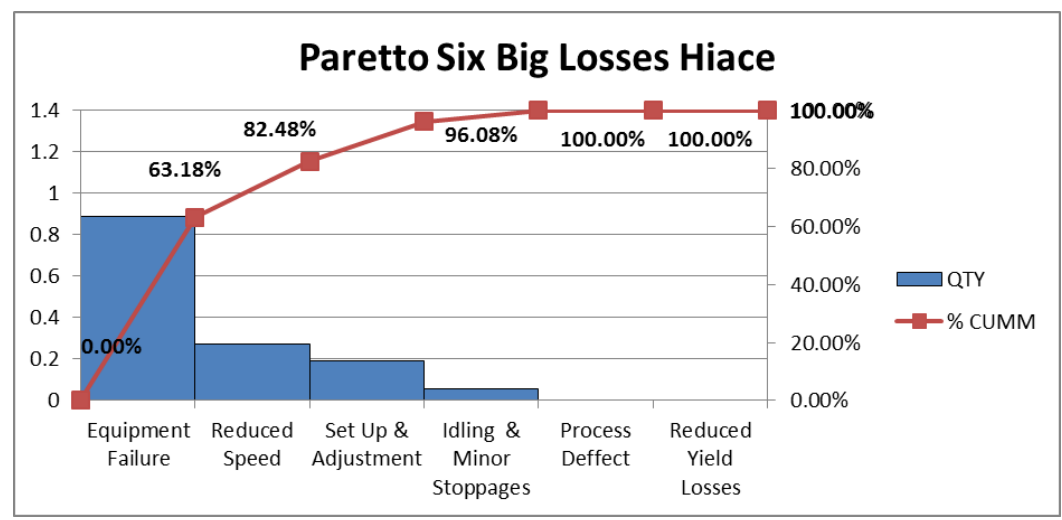

Fig-7: Diagram of Six Big Losses Toyota Bfree's Paretto Calculation

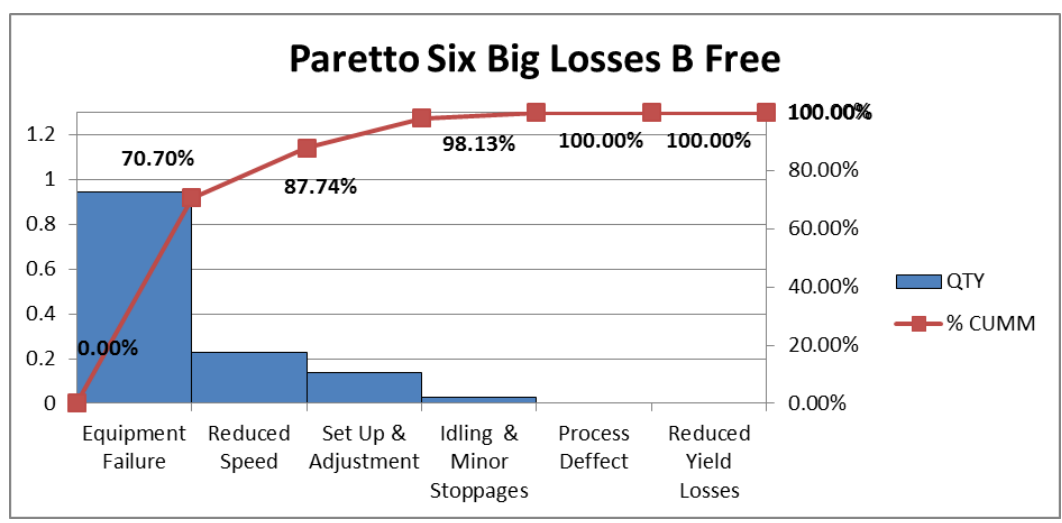

Fig-8: Diagram of Six Big Losses Toyota Hiace's Paretto Calculation 


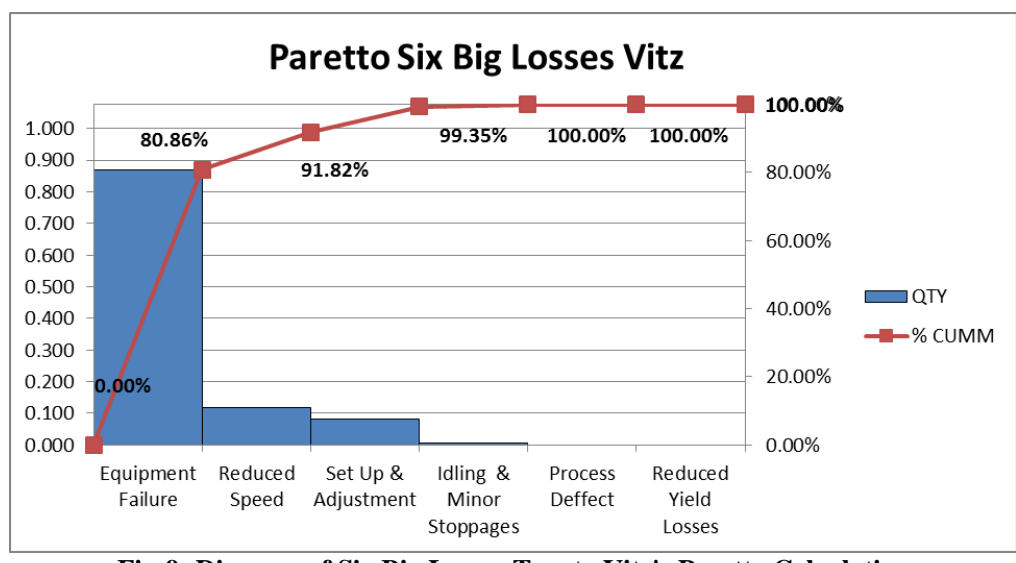

Fig-9: Diagram of Six Big Losses Toyota Vitz's Paretto Calculation

Through the Paretto Diagram, we found that the lowest score on the Six Big Losses calculation on the three carlines is the score of Equipment Failure. Next, those scores are held as a focus to fix the OEE score achievement on the three carlines by analyze it using the Fishbone Diagram and then finding the solution to fix the OEE score achievement of carline Toyota B Free which is applicable for the company.
Cause - Effect Diagram (Fishbone Diagram) OEE calculation result

According to Paretto Diagram, the result of the Overall Equipment Effectiveness calculation can figure out the main problem from the three carline. The lowest result from the OEE calculations becomes the main focus on the problem and analysed further with Fishbone Diagram method such as below:

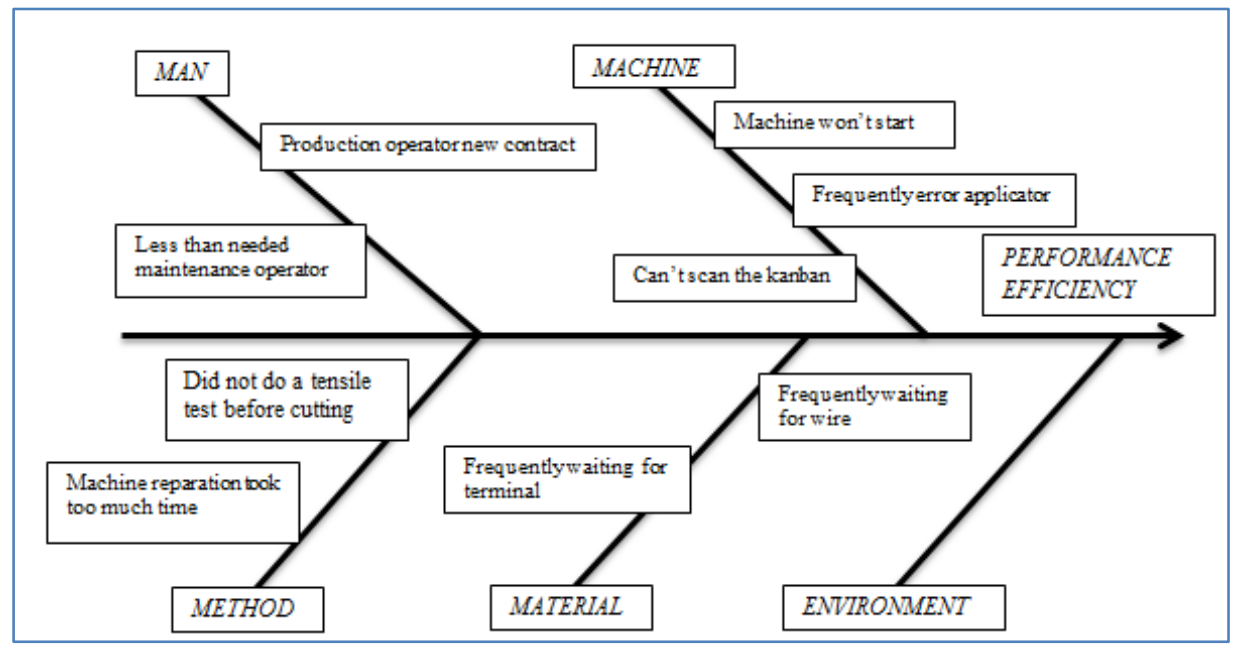

Fig-10: Fishbone Diagram Performance Efficiency Carline Toyota Bfree

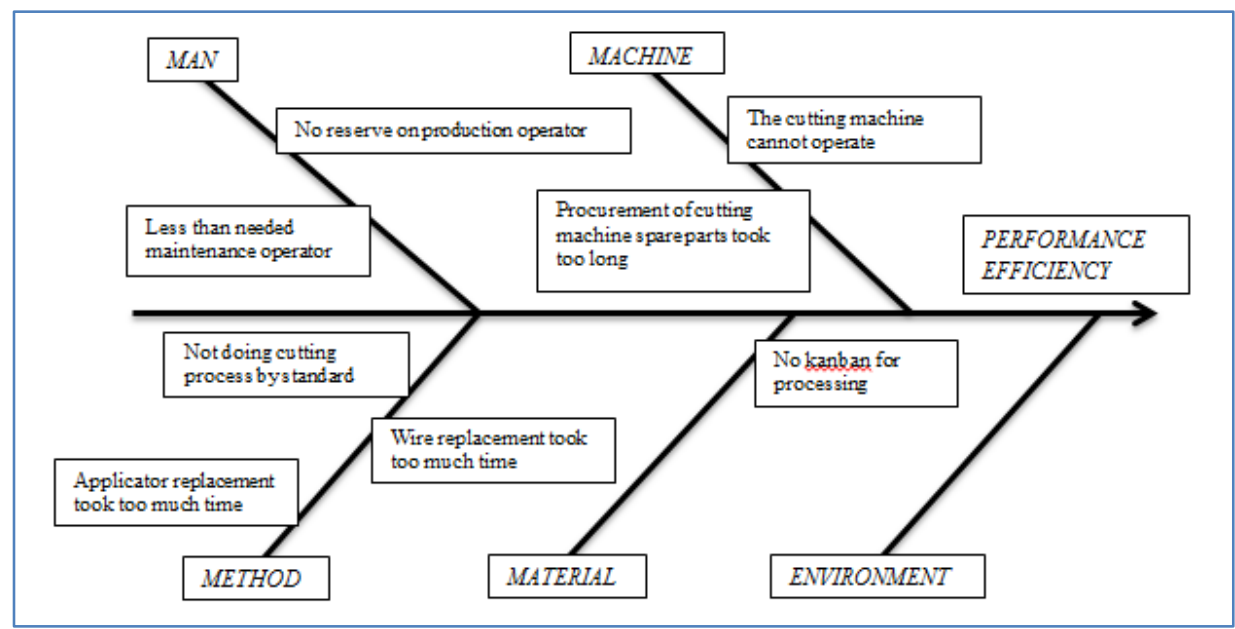

Fig-11: Fishbone Diagram Performance Efficiency Carline Toyota Hiace 


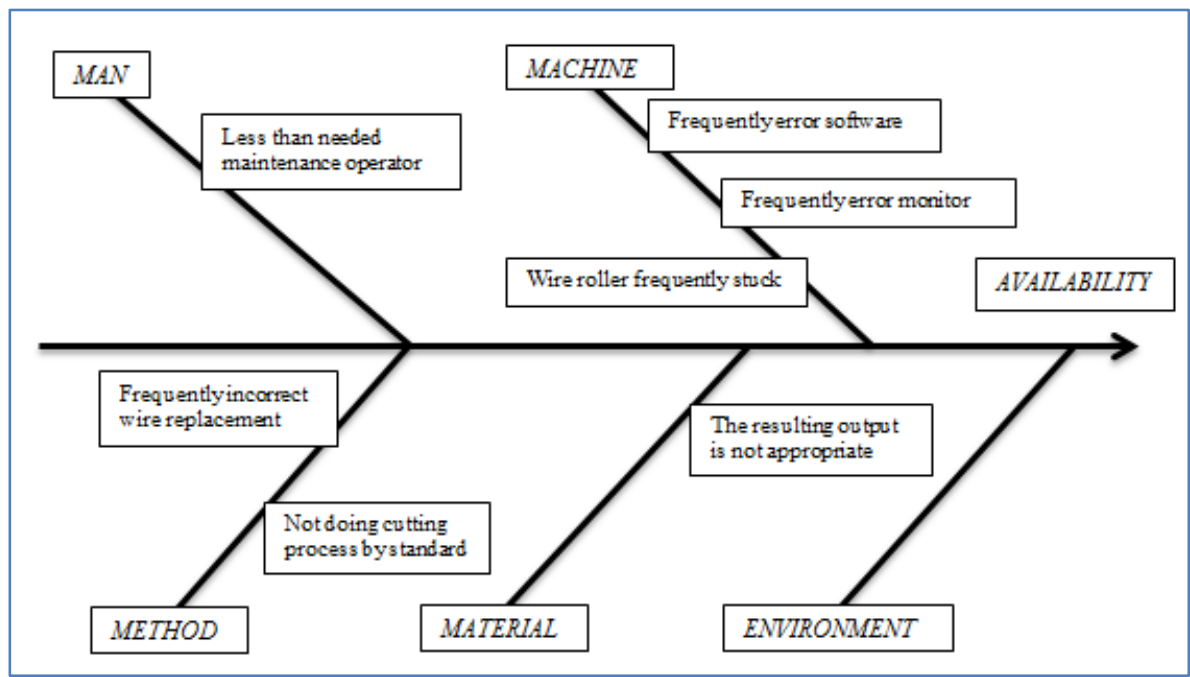

Fig-12: Fishbone Diagram Performance Efficiency Carline Toyota Vitz

Cause - Effect Diagram (Fishbone Diagram) calculation result of Six Big Losses

According to Paretto Diagram, the result of the problem from the three carlines. The lowest result from the Six Big Losses calculations becomes the main focus on the problem and analysed further with Fishbone Diagram method such as below:

Six Big Losses calculation can figure out the main

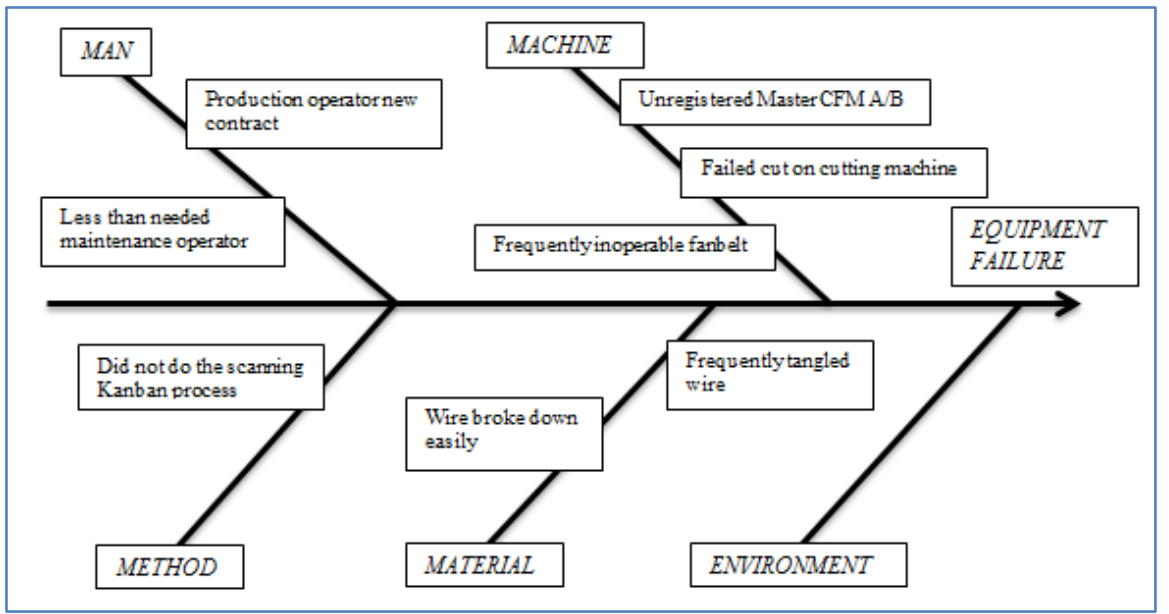

Fig-13: Fishbone Diagram Equipment Failure Carline Toyota Bfree

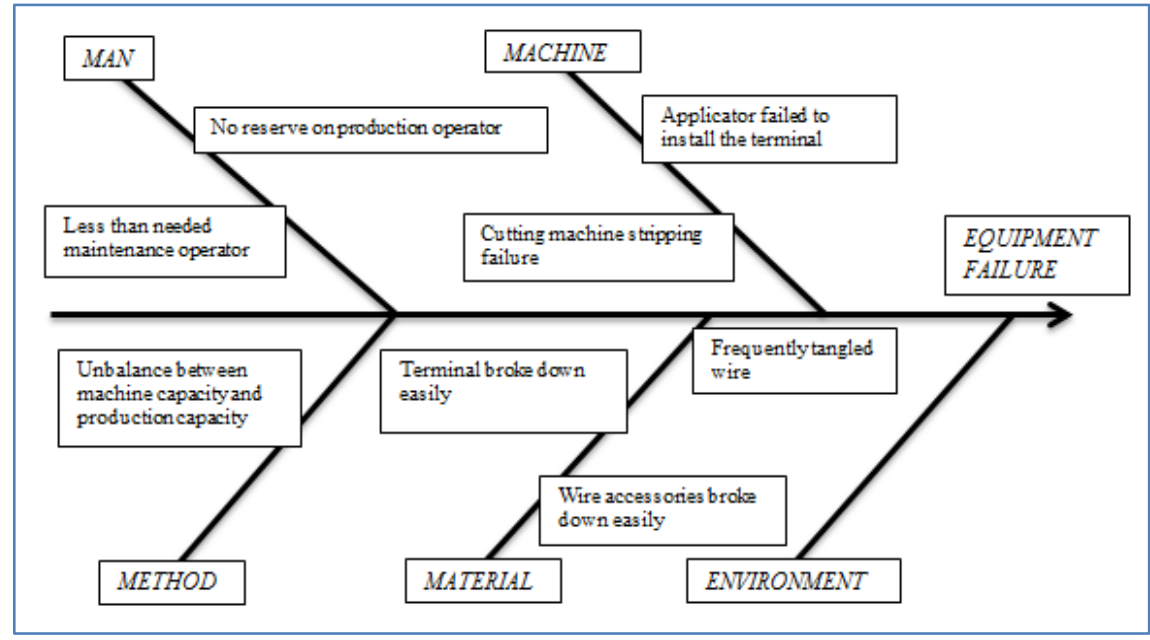

Fig-14: Fishbone Diagram Equipment Failure Carline Toyota Hiace 


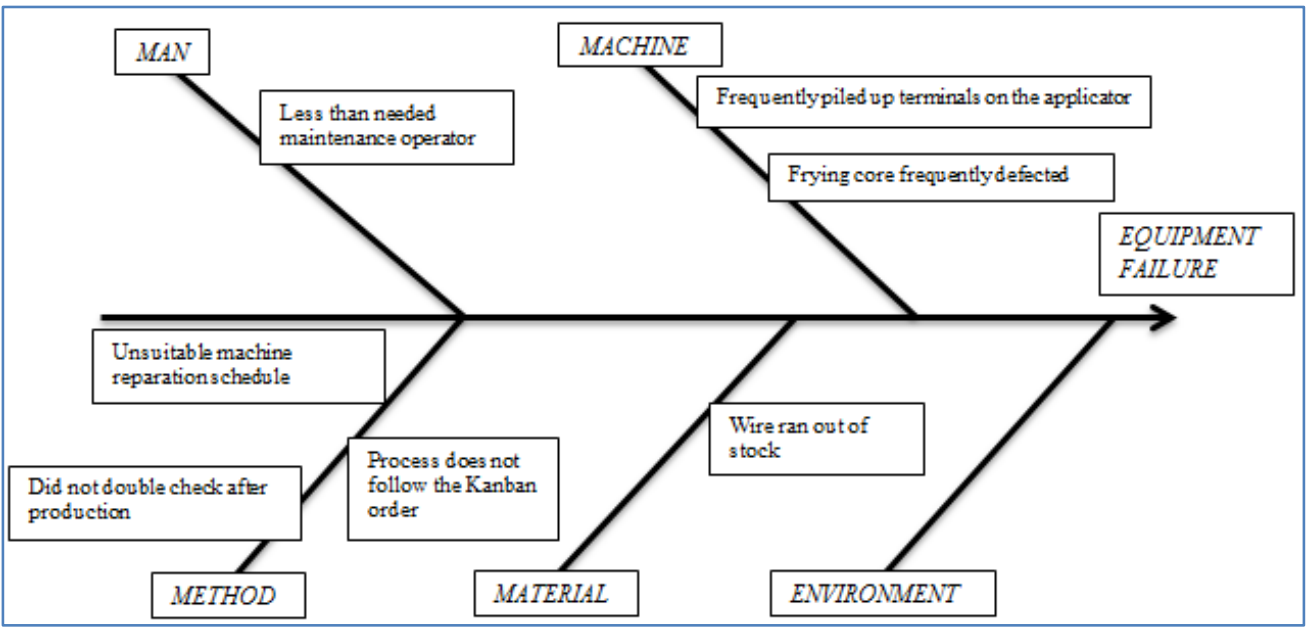

Fig-15: Fishbone Diagram Equipment Failure Carline Toyota Vitz

\section{Problem Solving}

The solution for this problem can be found by doing an extensive analysis on the main problem using the Fishbone Diagram with why - why analysis method until we found the suitable solution to do an accurate restoration such as the table below:

Table-7: Solution of Oee and Six Big Losses Problems Carline Toyota BFree

\begin{tabular}{|c|c|c|c|c|}
\hline \multicolumn{5}{|c|}{ Overall Equipment Effectiveness } \\
\hline Man & Why 1 & Why 2 & Why 3 & Corrective Solution \\
\hline $\begin{array}{l}\text { Production } \\
\text { operator new } \\
\text { contract }\end{array}$ & $\begin{array}{l}\text { Previous } \\
\text { operator's } \\
\text { contract expired } \\
\text { at the same time }\end{array}$ & $\begin{array}{l}\text { The company did } \\
\text { not being cautious } \\
\text { about the operator's } \\
\text { contract term }\end{array}$ & & $\begin{array}{l}\text { The company must cautiously register the } \\
\text { operator's contract term so that it will not } \\
\text { clash against the new contact }\end{array}$ \\
\hline $\begin{array}{l}\text { Less than } \\
\text { needed } \\
\text { maintenance } \\
\text { operator }\end{array}$ & $\begin{array}{l}1 \text { maintenance } \\
\text { operator per } 3 \\
\text { carlines }\end{array}$ & $\begin{array}{l}\text { The company's } \\
\text { efficiency policy }\end{array}$ & & $\begin{array}{l}\text { Maintenance operator procurement must } \\
\text { be suited for the chances of machine } \\
\text { breaking down }\end{array}$ \\
\hline Machine & Why 1 & Why 2 & Why 3 & Corrective Solution \\
\hline $\begin{array}{l}\text { The machine } \\
\text { will not start }\end{array}$ & $\begin{array}{l}\text { Machine } \\
\text { operation failure }\end{array}$ & $\begin{array}{l}\text { Lack of annual } \\
\text { machine checking }\end{array}$ & $\begin{array}{l}\text { Annual machine } \\
\text { checking not } \\
\text { operating } \\
\text { optimally }\end{array}$ & $\begin{array}{l}\text { Create a schedule on annual machine } \\
\text { checking on the cutting machine }\end{array}$ \\
\hline $\begin{array}{l}\text { Frequently } \\
\text { error applicator }\end{array}$ & $\begin{array}{l}\text { Terminal not } \\
\text { connected to the } \\
\text { circuit }\end{array}$ & $\begin{array}{l}\text { Damage on dice } \\
\text { applicator }\end{array}$ & & $\begin{array}{l}\text { Register the maximum use of the dice so } \\
\text { that it will not break down before it is } \\
\text { replaced }\end{array}$ \\
\hline \multirow[t]{2}{*}{$\begin{array}{l}\text { Cannot scan } \\
\text { the kanban }\end{array}$} & $\begin{array}{l}\text { New Kanban is } \\
\text { not recorded yet }\end{array}$ & Kanban is outdated & $\begin{array}{l}\text { PPIC } \\
\text { Department has } \\
\text { not informed the } \\
\text { Production } \\
\text { Department } \\
\text { about the new } \\
\text { kanban }\end{array}$ & $\begin{array}{l}\text { Teamwork and communication must be } \\
\text { increased to avoid outdated kanban }\end{array}$ \\
\hline & $\begin{array}{l}\text { Barcode scanner } \\
\text { cannot scan the } \\
\text { kanban }\end{array}$ & $\begin{array}{l}\text { Barcode scanner } \\
\text { breaks }\end{array}$ & & $\begin{array}{l}\text { Replacement for the broken barcode } \\
\text { scanner }\end{array}$ \\
\hline Method & Why 1 & Why 2 & Why 3 & Corrective Solution \\
\hline $\begin{array}{l}\text { Did not do a } \\
\text { tensile test } \\
\text { before cutting } \\
\text { process }\end{array}$ & $\begin{array}{l}\text { Operator lack the } \\
\text { knowledge about } \\
\text { tensile test }\end{array}$ & $\begin{array}{l}\text { Lack of } \\
\text { information about } \\
\text { the importance of } \\
\text { tensile test }\end{array}$ & & $\begin{array}{l}\text { Socialization about the importance of } \\
\text { tensile test to the operator in training }\end{array}$ \\
\hline \multirow[t]{2}{*}{$\begin{array}{l}\text { Machine } \\
\text { reparation took } \\
\text { too long }\end{array}$} & $\begin{array}{l}\text { Lack of } \\
\text { maintenance } \\
\text { operator }\end{array}$ & & & $\begin{array}{l}\text { Adjusting the amount of maintenance } \\
\text { operator to the carlines }\end{array}$ \\
\hline & $\begin{array}{l}\text { Lack of } \\
\text { understanding of } \\
\text { machine damages }\end{array}$ & $\begin{array}{l}\text { Insufficiency } \\
\text { training/retraining } \\
\text { time for the operator }\end{array}$ & & $\begin{array}{l}\text { Training/retraining the maintenance } \\
\text { operator on the cutting machine } \\
\text { intensively }\end{array}$ \\
\hline
\end{tabular}


Rosalendro Eddy Nugroho \& Syifa Khoirudin; Saudi J Bus Manag Stud, Jan., 2020; 5(1): 84-98

\begin{tabular}{|c|c|c|c|c|}
\hline Material & Why 1 & Why 2 & Why 3 & Corrective Solution \\
\hline $\begin{array}{l}\text { Frequently } \\
\text { waiting for the } \\
\text { wire }\end{array}$ & $\begin{array}{l}\text { Did not update } \\
\text { the wire stock }\end{array}$ & $\begin{array}{l}\text { Did not monitor the } \\
\text { wire stock } \\
\text { periodically }\end{array}$ & & $\begin{array}{l}\text { The company must monitor and register } \\
\text { the stock of wire to ask for new stock } \\
\text { before the wire runs out }\end{array}$ \\
\hline $\begin{array}{l}\text { Frequently } \\
\text { waiting for the } \\
\text { terminal }\end{array}$ & $\begin{array}{l}\text { Deliver the wrong } \\
\text { type of terminal }\end{array}$ & $\begin{array}{l}\text { Did not see the } \\
\text { terminal code } \\
\text { before delivery }\end{array}$ & & $\begin{array}{l}\text { The company must be thorough before } \\
\text { delivering the terminal }\end{array}$ \\
\hline Environment & Why 1 & Why 2 & Why 3 & Corrective Solution \\
\hline \multicolumn{5}{|c|}{ No need for improvement because there is not a factor that affects the OEE score. } \\
\hline \multicolumn{5}{|c|}{ Six Big Losses } \\
\hline Man & Why 1 & Why 2 & Why 3 & Corrective Solution \\
\hline $\begin{array}{l}\text { Production } \\
\text { Operator new } \\
\text { contract }\end{array}$ & $\begin{array}{l}\text { Previous } \\
\text { operator's } \\
\text { contract expired } \\
\text { at the same time }\end{array}$ & $\begin{array}{l}\text { The company did } \\
\text { not being cautious } \\
\text { about operator's } \\
\text { contract term }\end{array}$ & & $\begin{array}{l}\text { The company must cautiously register the } \\
\text { operator's contract term so that it will not } \\
\text { clash against the new contact }\end{array}$ \\
\hline $\begin{array}{l}\text { Less than } \\
\text { needed } \\
\text { maintenance } \\
\text { operator }\end{array}$ & $\begin{array}{l}1 \text { maintenance } \\
\text { operator per } 3 \\
\text { carlines }\end{array}$ & $\begin{array}{l}\text { Company's } \\
\text { efficiency policy }\end{array}$ & & $\begin{array}{l}\text { Maintenance operator procurement must } \\
\text { be suited for the chances of machine } \\
\text { breaking down }\end{array}$ \\
\hline Machine & Why 1 & Why 2 & Why 3 & Corrective Solution \\
\hline $\begin{array}{l}\text { Unregistered } \\
\text { Master CFM } \\
\text { A/B }\end{array}$ & $\begin{array}{l}\text { Outdated on the } \\
\text { new type of } \\
\text { defect }\end{array}$ & $\begin{array}{l}\text { Unregistered } \\
\text { Master CFM A/B } \\
\text { program by the } \\
\text { maintenance } \\
\text { operator }\end{array}$ & & $\begin{array}{l}\text { The company must update on the new } \\
\text { type of defect on the Master CFM A/B }\end{array}$ \\
\hline $\begin{array}{l}\text { Failed cut on } \\
\text { the cutting } \\
\text { machine }\end{array}$ & $\begin{array}{l}\text { Inoperable blade } \\
\text { on the cutting } \\
\text { machine }\end{array}$ & $\begin{array}{l}\text { Blade is already on } \\
\text { the maximum } \\
\text { usage capacity }\end{array}$ & $\begin{array}{l}\text { Unregistered } \\
\text { maximum usage } \\
\text { of the blade on } \\
\text { cutting machine }\end{array}$ & $\begin{array}{l}\text { The company must register the maximum } \\
\text { usage of the blade to find a replacement } \\
\text { before the blade reaches the maximum } \\
\text { usage capacity }\end{array}$ \\
\hline $\begin{array}{l}\text { Frequently } \\
\text { inoperable } \\
\text { fanbelt }\end{array}$ & Fanbelt stuck & Lack of lubrication & & $\begin{array}{l}\text { The company must regularly check the } \\
\text { fanbelt physically }\end{array}$ \\
\hline Method & Why 1 & Why 2 & Why 3 & Corrective Solution \\
\hline $\begin{array}{l}\text { The cutting } \\
\text { process did not } \\
\text { scan the } \\
\text { kanban }\end{array}$ & $\begin{array}{l}\text { Did not do the } \\
\text { cutting process by } \\
\text { the standard }\end{array}$ & $\begin{array}{l}\text { The operator wants } \\
\text { to do the cutting } \\
\text { process quicker }\end{array}$ & & $\begin{array}{l}\text { Supervising by the line leader and } \\
\text { retraining of the importance on the } \\
\text { scanning Kanban before the cutting } \\
\text { process }\end{array}$ \\
\hline Material & Why 1 & Why 2 & Why 3 & Corrective Solution \\
\hline \multirow[t]{2}{*}{$\begin{array}{l}\text { Frequently } \\
\text { tangled wire }\end{array}$} & $\begin{array}{l}\text { A lot of small and } \\
\text { long wire } \\
\text { dimension }\end{array}$ & $\begin{array}{l}\text { Consumer } \\
\text { specification }\end{array}$ & & $\begin{array}{l}\text { Specific handling on the long and small } \\
\text { wire, starts with the rolling the wire to the } \\
\text { distribution }\end{array}$ \\
\hline & $\begin{array}{l}\text { The rolling } \\
\text { process from the } \\
\text { big roll to the } \\
\text { bobbin is not } \\
\text { well-kept }\end{array}$ & $\begin{array}{l}\text { The rolling process } \\
\text { was rash }\end{array}$ & & $\begin{array}{l}\text { The rolling process to the bobbin wire } \\
\text { must be done carefully and precisely }\end{array}$ \\
\hline $\begin{array}{l}\text { Wire broke } \\
\text { down easily }\end{array}$ & $\begin{array}{l}\text { Thin protective } \\
\text { skin on the wire }\end{array}$ & $\begin{array}{l}\text { Consumer } \\
\text { specification and } \\
\text { the distributor's } \\
\text { quality }\end{array}$ & & $\begin{array}{l}\text { The company must ask the consumer } \\
\text { does changing the wire is necessary or } \\
\text { not, if not, specific handling is required } \\
\text { on the easily broke down wire }\end{array}$ \\
\hline Environment & Why 1 & Why 2 & Why 3 & Corrective Solution \\
\hline
\end{tabular}

Source: Self elaborated 
Table-8: Solution of Oee and Six Big Losses Problems Carline Toyota Hiace

\begin{tabular}{|c|c|c|c|c|}
\hline \multicolumn{5}{|c|}{ Overall Equipment Effectiveness } \\
\hline Man & Why 1 & Why 2 & Why 3 & Corrective Solution \\
\hline $\begin{array}{l}\text { No reserve on } \\
\text { the production } \\
\text { operator }\end{array}$ & $\begin{array}{l}\text { A lot of operator } \\
\text { does not come up at } \\
\text { the same time }\end{array}$ & $\begin{array}{l}\text { The company's policy } \\
\text { on leave permission } \\
\text { and furlough }\end{array}$ & & $\begin{array}{l}\text { The company must regulate on the } \\
\text { policy of leave permission and } \\
\text { furlough }\end{array}$ \\
\hline $\begin{array}{l}\text { Less than needed } \\
\text { maintenance } \\
\text { operator }\end{array}$ & $\begin{array}{l}1 \text { maintenance } \\
\text { operator per } 3 \\
\text { carlines }\end{array}$ & $\begin{array}{l}\text { Company’s efficiency } \\
\text { policy }\end{array}$ & & $\begin{array}{l}\text { Maintenance operator procurement } \\
\text { must be suited for the chances of } \\
\text { machine breaking down }\end{array}$ \\
\hline Machine & Why 1 & Why 2 & Why 3 & Corrective Solution \\
\hline $\begin{array}{l}\text { The cutting } \\
\text { machine cannot } \\
\text { operate }\end{array}$ & $\begin{array}{l}\text { Frequent error on } \\
\text { machine operation }\end{array}$ & $\begin{array}{l}\text { Lack of annual } \\
\text { machine checking }\end{array}$ & $\begin{array}{l}\text { Production operator and } \\
\text { maintenance operator } \\
\text { are careless about } \\
\text { cutting machines } \\
\text { condition }\end{array}$ & $\begin{array}{l}\text { Socialization to production } \\
\text { operator and maintenance operator } \\
\text { to start paying attention to the } \\
\text { cutting machine condition and } \\
\text { regularly check on the cutting } \\
\text { machine }\end{array}$ \\
\hline \multirow[t]{2}{*}{$\begin{array}{l}\text { Spare part } \\
\text { replacement took } \\
\text { too much time }\end{array}$} & $\begin{array}{l}\text { Spare part ran out of } \\
\text { stock }\end{array}$ & $\begin{array}{l}\text { Machine spare parts } \\
\text { were not registered }\end{array}$ & & $\begin{array}{l}\text { The company must register all the } \\
\text { spare parts needed by the cutting } \\
\text { machine }\end{array}$ \\
\hline & $\begin{array}{l}\text { Spare part delivery } \\
\text { took too long }\end{array}$ & $\begin{array}{l}\text { Spare parts were } \\
\text { imported from Japan }\end{array}$ & & $\begin{array}{l}\text { The company must order the spare } \\
\text { part according to the necessity and } \\
\text { must be done before replacement }\end{array}$ \\
\hline Method & Why 1 & Why 2 & Why 3 & Corrective Solution \\
\hline $\begin{array}{l}\text { Cutting process } \\
\text { does not follow } \\
\text { the standard } \\
\text { procedure }\end{array}$ & $\begin{array}{l}\text { Work was done by a } \\
\text { recitation }\end{array}$ & $\begin{array}{l}\text { The operator wants to } \\
\text { do the cutting process } \\
\text { quicker }\end{array}$ & $\begin{array}{l}\text { Meeting the target of } \\
\text { cutting output }\end{array}$ & $\begin{array}{l}\text { In the training process, there must } \\
\text { be socialization about the } \\
\text { importance of procedure and fit } \\
\text { quality and quantity }\end{array}$ \\
\hline $\begin{array}{l}\text { Wire } \\
\text { replacement took } \\
\text { too much time }\end{array}$ & $\begin{array}{l}\text { Wires were not } \\
\text { placed on the } \\
\text { corresponding } \\
\text { storage }\end{array}$ & $\begin{array}{l}\text { MPC Operator did not } \\
\text { do a thorough job on } \\
\text { storing the wire }\end{array}$ & & $\begin{array}{l}\text { Line Leader must supervise and } \\
\text { guide the storing process to ensure } \\
\text { wires were stored appropriately }\end{array}$ \\
\hline $\begin{array}{l}\text { Applicator } \\
\text { replacement took } \\
\text { too much time }\end{array}$ & $\begin{array}{l}\text { Applicators were not } \\
\text { placed on the } \\
\text { corresponding } \\
\text { storage }\end{array}$ & $\begin{array}{l}\text { Production Operator } \\
\text { did not do a thorough } \\
\text { job on storing the } \\
\text { applicators after use }\end{array}$ & & $\begin{array}{l}\text { Line Leader must supervise and } \\
\text { guide the storing process to ensure } \\
\text { applicators were stored } \\
\text { appropriately after use }\end{array}$ \\
\hline Material & Why 1 & Why 2 & Why 3 & Corrective Solution \\
\hline \multirow[t]{2}{*}{$\begin{array}{l}\text { No kanban to } \\
\text { process }\end{array}$} & $\begin{array}{l}\text { A lot of kanbans are } \\
\text { missing }\end{array}$ & $\begin{array}{l}\text { Slip inside the circuit } \\
\text { store or stolen }\end{array}$ & $\begin{array}{l}\text { Lack of supervising and } \\
\text { registering the actual } \\
\text { quantity of kanban }\end{array}$ & $\begin{array}{l}\text { The company must supervise and } \\
\text { register the actual quantity of } \\
\text { kanban }\end{array}$ \\
\hline & $\begin{array}{l}\text { New type of process } \\
\text { kanban }\end{array}$ & $\begin{array}{l}\text { PPIC lateness on } \\
\text { delivering kanban }\end{array}$ & $\begin{array}{l}\text { PPIC did not } \\
\text { communicate with } \\
\text { Production about the } \\
\text { kanban change }\end{array}$ & $\begin{array}{l}\text { PPIC must communicate if there is } \\
\text { a change in process kanban }\end{array}$ \\
\hline Environtment & Why 1 & Why 2 & Why 3 & Corrective Solution \\
\hline \multicolumn{5}{|c|}{ No need for improvement because there is not a factor that affects the OEE score. } \\
\hline \multicolumn{5}{|c|}{ Six Big Losses } \\
\hline Man & Why 1 & Why 2 & Why 3 & Corrective Solution \\
\hline $\begin{array}{l}\text { No reserve on } \\
\text { the production } \\
\text { operator }\end{array}$ & $\begin{array}{l}\text { A lot of operator } \\
\text { does not come up at } \\
\text { the same time }\end{array}$ & $\begin{array}{l}\text { The company's policy } \\
\text { on leave permission } \\
\text { and furlough }\end{array}$ & & $\begin{array}{l}\text { The company must regulate on the } \\
\text { policy of leave permission and } \\
\text { furlough }\end{array}$ \\
\hline $\begin{array}{l}\text { Less than needed } \\
\text { maintenance } \\
\text { operator }\end{array}$ & $\begin{array}{l}1 \text { maintenance } \\
\text { operator per } 3 \\
\text { carlines }\end{array}$ & $\begin{array}{l}\text { Company's efficiency } \\
\text { policy }\end{array}$ & & $\begin{array}{l}\text { Maintenance operator procurement } \\
\text { must be suited for the chances of } \\
\text { machine breaking down }\end{array}$ \\
\hline Machine & Why 1 & Why 2 & Why 3 & Corrective Solution \\
\hline \multirow[t]{2}{*}{$\begin{array}{l}\text { Applicator failed } \\
\text { to install the } \\
\text { terminal }\end{array}$} & $\begin{array}{l}\text { Dice on the } \\
\text { applicator not } \\
\text { working properly }\end{array}$ & $\begin{array}{l}\text { Dice has reached } \\
\text { maximum usage }\end{array}$ & $\begin{array}{l}\text { Not communicating } \\
\text { about dice applicator } \\
\text { replacement before the } \\
\text { dice reached maximum } \\
\text { usage capacity }\end{array}$ & $\begin{array}{l}\text { The company should replace the } \\
\text { dice applicator before it reached } \\
\text { the maximum usage capacity }\end{array}$ \\
\hline & $\begin{array}{l}\text { Damage on the } \\
\text { applicator }\end{array}$ & $\begin{array}{l}\text { Applicator usage } \\
\text { capacity }\end{array}$ & & $\begin{array}{l}\text { The company should apply specific } \\
\text { handling to prolong the usage of } \\
\text { the applicator. If it already reached } \\
\text { its' maximum usage capacity, the } \\
\text { company should buy the } \\
\text { replacement immediately }\end{array}$ \\
\hline
\end{tabular}




\begin{tabular}{|c|c|c|c|c|}
\hline $\begin{array}{l}\text { Cutting machine } \\
\text { stripping failure }\end{array}$ & $\begin{array}{l}\text { Cutting machine } \\
\text { stripping blade now } \\
\text { working properly }\end{array}$ & $\begin{array}{l}\text { Stripping blade } \\
\text { already reached its' } \\
\text { maximum usage } \\
\text { capacity }\end{array}$ & $\begin{array}{l}\text { Registering censor on } \\
\text { cutting machine } \\
\text { stripping blade not } \\
\text { functioning }\end{array}$ & $\begin{array}{l}\text { The company should replace the } \\
\text { registering censor in cutting } \\
\text { machine stripping blade so } \\
\text { replacement would happen before } \\
\text { it reached maximum usage } \\
\text { capacity }\end{array}$ \\
\hline Method & Why 1 & Why 2 & Why 3 & Corrective Solution \\
\hline $\begin{array}{l}\text { Unbalance } \\
\text { between machine } \\
\text { capacity and } \\
\text { production } \\
\text { capacity }\end{array}$ & $\begin{array}{l}\text { Increasing cutting } \\
\text { output target on the } \\
\text { machine }\end{array}$ & $\begin{array}{l}\text { Increased kanban } \\
\text { quantity }\end{array}$ & $\begin{array}{l}\text { Consumer order } \\
\text { increased }\end{array}$ & $\begin{array}{l}\text { Changing the method on the } \\
\text { kanban quantity with increasing } \\
\text { the amount of kanbans that are } \\
\text { circulating }\end{array}$ \\
\hline Material & Why 1 & Why 2 & Why 3 & Corrective Solution \\
\hline \multirow[t]{2}{*}{$\begin{array}{l}\text { Frequently } \\
\text { tangled wire }\end{array}$} & $\begin{array}{l}\text { A lot of small and } \\
\text { long wire dimension }\end{array}$ & $\begin{array}{l}\text { Consumer } \\
\text { specification }\end{array}$ & & $\begin{array}{l}\text { Specific handling on the long and } \\
\text { small wire, starts with the rolling } \\
\text { the wire to the distribution }\end{array}$ \\
\hline & $\begin{array}{l}\text { Rolling process } \\
\text { from the big roll to } \\
\text { the bobbin is not } \\
\text { well-kept }\end{array}$ & $\begin{array}{l}\text { The rolling process } \\
\text { was rash }\end{array}$ & & $\begin{array}{l}\text { The rolling process to the bobbin } \\
\text { wire must be done carefully and } \\
\text { precisely }\end{array}$ \\
\hline $\begin{array}{l}\text { Terminal broke } \\
\text { down easily }\end{array}$ & $\begin{array}{l}\text { Frequently banned } \\
\text { up/down on the } \\
\text { circuit terminal }\end{array}$ & $\begin{array}{l}\text { Circuit leveling } \\
\text { process after cutting } \\
\text { process was not done } \\
\text { on the provided space }\end{array}$ & & $\begin{array}{l}\text { On training, the company should } \\
\text { socialize about doing the circuit } \\
\text { leveling process on the provided } \\
\text { space }\end{array}$ \\
\hline $\begin{array}{l}\text { Wire accessories } \\
\text { broke down } \\
\text { easily }\end{array}$ & $\begin{array}{l}\text { Circuit rubber seal is } \\
\text { thin and easily tear } \\
\text { off }\end{array}$ & $\begin{array}{l}\text { Consumer } \\
\text { specification }\end{array}$ & & $\begin{array}{l}\text { Circuit rubber seal installation } \\
\text { process should be done separately } \\
\text { from the cutting machine for the } \\
\text { easily broke down rubber seal }\end{array}$ \\
\hline Environment & Why 1 & Why 2 & Why 3 & Corrective Solution \\
\hline
\end{tabular}

Source: Self elaborated

Table-9: Solution of Oee and Six Big Losses Problems Carline Toyota Vitz

\begin{tabular}{|c|c|c|c|c|}
\hline \multicolumn{5}{|c|}{ Overall Equipment Effectiveness } \\
\hline Man & Why 1 & Why 2 & Why 3 & Corrective Solution \\
\hline $\begin{array}{l}\text { Less than } \\
\text { needed } \\
\text { maintenance } \\
\text { operator }\end{array}$ & $\begin{array}{l}1 \text { maintenance } \\
\text { operator per } 3 \\
\text { carlines }\end{array}$ & $\begin{array}{l}\text { Company's } \\
\text { efficiency policy }\end{array}$ & & $\begin{array}{l}\text { Maintenance operator procurement } \\
\text { must be suited for the chances of } \\
\text { machine breaking down }\end{array}$ \\
\hline Machine & Why 1 & Why 2 & Why 3 & Corrective Solution \\
\hline $\begin{array}{l}\text { Frequently error } \\
\text { software }\end{array}$ & $\begin{array}{l}\text { Cutting machine } \\
\text { software is } \\
\text { unrecognized } \\
\text { when operated }\end{array}$ & $\begin{array}{l}\text { Software got } \\
\text { virus }\end{array}$ & & $\begin{array}{l}\text { Prevention should be done by doing } \\
\text { a check-up regularly and installing } \\
\text { antivirus on the software }\end{array}$ \\
\hline $\begin{array}{l}\text { Frequently error } \\
\text { monitor }\end{array}$ & $\begin{array}{l}\text { Monitor turns off } \\
\text { by itself } \\
\text { frequently when } \\
\text { operating the } \\
\text { cutting machine }\end{array}$ & $\begin{array}{l}\text { Monitor is worn } \\
\text { out }\end{array}$ & & $\begin{array}{l}\text { Replacing monitor that has been } \\
\text { worn out }\end{array}$ \\
\hline $\begin{array}{l}\text { Wire roller } \\
\text { frequently stuck }\end{array}$ & $\begin{array}{l}\text { Wire not working } \\
\text { properly when } \\
\text { processing }\end{array}$ & $\begin{array}{l}\text { Roller insert } \\
\text { surface is } \\
\text { sluggish }\end{array}$ & $\begin{array}{l}\text { Lack of } \\
\text { lubrication on } \\
\text { roller insert wire }\end{array}$ & $\begin{array}{l}\text { Cutting operator must lubricate the } \\
\text { roller insert wire periodically }\end{array}$ \\
\hline Method & Why 1 & Why 2 & Why 3 & Corrective Solution \\
\hline $\begin{array}{l}\text { Frequently } \\
\text { incorrect wire } \\
\text { replacement }\end{array}$ & $\begin{array}{l}\text { Cutting operator } \\
\text { use the wrong } \\
\text { wire type }\end{array}$ & $\begin{array}{l}\text { Wires were not } \\
\text { stored in the } \\
\text { corresponding } \\
\text { wire storage }\end{array}$ & $\begin{array}{l}\text { Wires were } \\
\text { wrongly stored in } \\
\text { the distribution } \\
\text { process }\end{array}$ & $\begin{array}{l}\text { Wire storing process must follow } \\
\text { the corresponding storage instead } \\
\text { of placing it with the same color }\end{array}$ \\
\hline $\begin{array}{l}\text { Not doing } \\
\text { cutting process } \\
\text { by standard }\end{array}$ & $\begin{array}{l}\text { Work was done } \\
\text { by a recitation }\end{array}$ & $\begin{array}{l}\text { The operator } \\
\text { wants to do the } \\
\text { cutting process } \\
\text { quicker }\end{array}$ & $\begin{array}{l}\text { Meeting the } \\
\text { target of cutting } \\
\text { output }\end{array}$ & $\begin{array}{l}\text { In the training process, there must } \\
\text { be socialization about the } \\
\text { importance of procedure and a fit } \\
\text { quality and quantity }\end{array}$ \\
\hline
\end{tabular}


Rosalendro Eddy Nugroho \& Syifa Khoirudin; Saudi J Bus Manag Stud, Jan., 2020; 5(1): 84-98

\begin{tabular}{|c|c|c|c|c|}
\hline Material & Why 1 & Why 2 & Why 3 & Corrective Solution \\
\hline $\begin{array}{l}\text { The resulting } \\
\text { output is not } \\
\text { appropriate }\end{array}$ & $\begin{array}{l}\text { Kanbans were } \\
\text { uneven with the } \\
\text { expected output }\end{array}$ & $\begin{array}{l}\text { Lack of kanban to } \\
\text { process }\end{array}$ & $\begin{array}{l}\text { Kanban updates } \\
\text { were late }\end{array}$ & $\begin{array}{l}\text { The company must adjust the } \\
\text { amount of Kanbans in production } \\
\text { with the expected output }\end{array}$ \\
\hline Environtment & Why 1 & Why 2 & Why 3 & Corrective Solution \\
\hline \multicolumn{5}{|c|}{ No need for improvement because there is not a factor that affects the OEE score. } \\
\hline \multicolumn{5}{|c|}{ Six Big Losses } \\
\hline Man & Why 1 & Why 2 & Why 3 & Corrective Solution \\
\hline $\begin{array}{l}\text { Less than } \\
\text { needed } \\
\text { maintenance } \\
\text { operator }\end{array}$ & $\begin{array}{l}1 \text { maintenance } \\
\text { operator per } 3 \\
\text { carlines }\end{array}$ & $\begin{array}{l}\text { Company's } \\
\text { efficiency policy }\end{array}$ & & $\begin{array}{l}\text { Maintenance operator procurement } \\
\text { must be suited for the chances of } \\
\text { machine breaking down }\end{array}$ \\
\hline Machine & Why 1 & Why 2 & Why 3 & Corrective Solution \\
\hline \multirow[t]{3}{*}{$\begin{array}{l}\text { Frequently piled } \\
\text { up terminals on } \\
\text { the applicator }\end{array}$} & \multirow{2}{*}{$\begin{array}{l}\text { There was a } \\
\text { mistake when } \\
\text { setting the } \\
\text { terminal in the } \\
\text { applicator }\end{array}$} & $\begin{array}{l}\text { Use the wrong } \\
\text { type of terminal }\end{array}$ & $\begin{array}{l}\text { Did not pay } \\
\text { attention to the } \\
\text { terminal's code in } \\
\text { use }\end{array}$ & $\begin{array}{l}\text { Operator must pay attention to the } \\
\text { terminal's code when picking up } \\
\text { the terminal to use with suitable } \\
\text { applicator }\end{array}$ \\
\hline & & $\begin{array}{l}\text { Terminals were } \\
\text { not set correctly }\end{array}$ & $\begin{array}{l}\text { The setting was } \\
\text { done in a rash }\end{array}$ & $\begin{array}{l}\text { The operator must set the terminal } \\
\text { thoroughly and as the procedure }\end{array}$ \\
\hline & Broken applicator & $\begin{array}{l}\text { Applicators were } \\
\text { not checked } \\
\text { regularly and } \\
\text { were not taken } \\
\text { care of }\end{array}$ & & $\begin{array}{l}\text { The company must prevent it by } \\
\text { taking care of the applicator } \\
\text { regularly and make a replacement } \\
\text { when it breaks }\end{array}$ \\
\hline $\begin{array}{l}\text { Frying core } \\
\text { frequently } \\
\text { defected }\end{array}$ & $\begin{array}{l}\text { Defect passed } \\
\text { through after the } \\
\text { cutting process }\end{array}$ & $\begin{array}{l}\text { Defect was not } \\
\text { seen by Master } \\
\text { CFM A/B }\end{array}$ & $\begin{array}{l}\text { Master CFM A/B } \\
\text { error or broken }\end{array}$ & $\begin{array}{l}\text { Prevention by checking the Master } \\
\text { CFM A/B regularly and make } \\
\text { reparation if it breaks }\end{array}$ \\
\hline Method & Why 1 & Why 2 & Why 3 & Corrective Solution \\
\hline $\begin{array}{l}\text { Machine } \\
\text { reparation } \\
\text { scheduling does } \\
\text { not suit the } \\
\text { schedule }\end{array}$ & $\begin{array}{l}\text { Maintenance } \\
\text { operator did not } \\
\text { repair the } \\
\text { machine on } \\
\text { schedule }\end{array}$ & $\begin{array}{l}\text { Reparation } \\
\text { schedule clash } \\
\text { with other } \\
\text { carlines }\end{array}$ & $\begin{array}{l}\text { Maintenance } \\
\text { operator are } \\
\text { limited }\end{array}$ & $\begin{array}{l}\text { Machine reparation schedule } \\
\text { should not clash with other carlines } \\
\text { and adjustment should be made } \\
\text { with the maintenance operator } \\
\text { available }\end{array}$ \\
\hline $\begin{array}{l}\text { Process did not } \\
\text { follow the } \\
\text { kanban }\end{array}$ & $\begin{array}{l}\text { Process was done } \\
\text { manually and did } \\
\text { not follow the } \\
\text { program }\end{array}$ & $\begin{array}{l}\text { Operator } \\
\text { accessing the } \\
\text { cutting program } \\
\text { without } \\
\text { permission }\end{array}$ & $\begin{array}{l}\text { Cutting process } \\
\text { with the same } \\
\text { type of wire was } \\
\text { done } \\
\text { simultaneously }\end{array}$ & $\begin{array}{l}\text { Maintenance operator should lock } \\
\text { the cutting program so the work } \\
\text { order will not be altered by the } \\
\text { cutting operator and supervised by } \\
\text { the line leader }\end{array}$ \\
\hline $\begin{array}{l}\text { Did not double- } \\
\text { check after } \\
\text { production }\end{array}$ & $\begin{array}{l}\text { Consider the } \\
\text { cutting output } \\
\text { was already as } \\
\text { standard }\end{array}$ & $\begin{array}{l}\text { Rushing to the } \\
\text { next process }\end{array}$ & & $\begin{array}{l}\text { Supervising by line leader so } \\
\text { ensure operator double-check after } \\
\text { every cutting process }\end{array}$ \\
\hline Material & Why 1 & Why 2 & Why 3 & Corrective Solution \\
\hline \multirow[t]{2}{*}{$\begin{array}{l}\text { Wire ran out of } \\
\text { stock }\end{array}$} & \multirow[t]{2}{*}{$\begin{array}{l}\text { Wires delivery to } \\
\text { the production } \\
\text { was late }\end{array}$} & \multirow[t]{2}{*}{$\begin{array}{l}\text { Wire is not } \\
\text { available on the } \\
\text { wire store }\end{array}$} & $\begin{array}{l}\text { The required wire } \\
\text { was used on } \\
\text { another carline }\end{array}$ & $\begin{array}{l}\text { Wire resupply must be suited for } \\
\text { each carline }\end{array}$ \\
\hline & & & $\begin{array}{l}\text { Wire supply } \\
\text { delivery was late } \\
\text { to restock }\end{array}$ & $\begin{array}{l}\text { The company must register the wire } \\
\text { stock thoroughly and reorder before } \\
\text { it ran out of stock }\end{array}$ \\
\hline Environment & Why 1 & Why 2 & Why 3 & Corrective Solution \\
\hline
\end{tabular}
Source: Self elaborated

\section{CONCLUSSIONS}

The conclusions that can be drawn from this study are:

1. The dominant factor for the low achievement of the OEE score on carline Toyoto Bfree is the Performance Efficiency of $72.56 \%$. The dominant factor for the low achievement of the OEE score on carline Toyota Hiace is the Performance Efficiency of 69.25. The dominant factor for the low achievement of the OEE score on carline Toyota Vitz is the Availability of $84.45 \%$. 
2. Based on the calculation of Six Big Losses on carline Toyota Bfree, carline Toyota Hiace, and carline Toyota Vitz the losses factor that frequently happened is the Equipment Failure.

\section{Advice}

1. The company need to consider about the worker recruitment system with a contract system, prepare the reserve operator for each carline to anticipate the absent of operator, also adjusting the amount of maintenance operator for carline production needs.

2. Do prevention on damaging the cutting machine by a precise scheduled machine handling and also take care of the machine accordingly with the schedule, do a repair on the machine accurately supported by maintenance operator's ability with spare part procurement so that spare part substitution will not slow down and damaging the cutting process.

3. Training and retraining system for the operators to understand and operate the job according to the procedure and company standard, better oversight by the line leader and supervisor, also make improvement to ease the operator's work process.

4. A ripe production preparation, material distribution process according to the cutting needs, and good communication between department and consumer about the choice of material being used.

\section{REFERENCES}

1. Nallusamy, S., \& Majumdar, G. (2017). Improvement of Overall Effectiveness Equipment using Total Productive Maintenance in the Manufacturing Industry. International Journal of Performability Teknik, 13(2), 173-188.

2. Alvira, D. (2015). Proposed Improvement of Overall Equipment Effectiveness (OEE) on Manual Tapping Machines by Minimizing Six Big Losses. Jurnal Online Institut Teknologi Nasional, 03(03), 240-251.

3. Subiyanto. (2014). Analysis of the Effectiveness of Sugar Machine Machinery/ Tools Using the Overall Equipments Effectiveness Method. Jurnal

Teknik Industri, $16(1), \quad 41-50$.

https://doi.org/10.9744/jti.16.1.41-50.

4. Kumar, T. V., Parthasarathi, M., Manojkumar, S., \& Selvaprakash, S. (2016). Lean Six Sigma Approach to Improve Overall Equipment Effectiveness Performance: A Case Study in the Indian Small Manufacturing Firm. International Journal for Innovative Research in Multidisciplinary Field, 2(12), 122-129.

5. Esmaeel. (2018). Understanding of Business Performance from the Perspective of Manufacturing Strategies: Fit Manufacturing and Overall Equipment Effectiveness. Procedia Manufacturing, 22, 998-1006. https://doi.org/10.1016/j.promfg.2018.03.142.

6. Eng, C. K., \& Choi, N. K. (2016). Relationship between Overall Equipment Effectiveness, Throughput and Production Part Cost in Semiconductor Manufacturing Industry. IEEE IEEM, 75-79.

7. Nurfaizah, U., Adianto, R. H., \& Prassetiyo, H. (2014). Design of Implementation of Total Productive Maintenance (TPM) in the Press Part II of PT. XYZ. Jurnal Online Institut Teknologi Nasional, 01(01), 340-353.

8. Coccia, M. (2017). The Fishbone Diagram to Identify, Systematize and Analyze The Sources of General Purpose Technologies. Journal of Social and Administrative Sciences, 4(4), 291-303. https://doi.org/10.1453/jsas.v4i4.1518.

9. Sagita, I. (2017). Performance Improvement of E5 Punching Machine and E150 Bending Production of Pix Panel Products with Overall Equipment Effectiveness (OEE) Method (Case Study of PT Schneider Indonesia-Pulogadung Plant).

10. Siddiq, M., Atmaji, F. T. D., \& Alhilman, J. (2018). Proposed Implementation of Total Productive Maintenance (TPM) to Increase Machine Effectiveness by Using the Overall Equipment Effectiveness (OEE) method at PT Sanbe Farma Cimareme Unit III Large Volume Parenteral Plant. E-Proceeding of Engineering, 5(2), 2982-2990. 